Article

\title{
The Revolutionary Spinoza: Immanence, Ethology, and the Politic of Desire
}

Raniel SM. Reyes

\begin{abstract}
This article is a reconstruction of Spinoza's materialist ontology using Deleuze's philosophy, towards a revolutionary ethics of desire. In the first part, I discuss the nature of Spinoza's radical ethics in conjunction with Deleuze's immanent ethics. Moreover, I elaborate Spinoza's philosophy of ethology and notion of agency (conatus). In the last part, I explain how these concepts have influenced Deleuze and Guattari's formulation of an immanent, minortarian, and collective politics of desire. In addition, I explicate how this radical theory of ethics can engender the diagramming of a nomadic politics or a revolution-to-come.
\end{abstract}

Keywords: ethology, conatus, schizoanalysis, cartography

\section{Spinoza's Materialist Ontology and the Plane of Immanence}

7 he philosopher, Deleuze describes in Spinoza: Practical Philosophy, appropriates the ascetic virtues of chastity, humility, and poverty, and lives it as the creative expression of his own singularity. ${ }^{1}$ Spinoza utilizes these virtues not to achieve moral ends or religious pathway towards an afterworld, "but rather the 'effects' of philosophy itself ... as there is absolutely no other life for the philosopher." 2 Meanwhile, in Expressionism in Philosophy: Spinoza, Deleuze considers Spinoza as the 'prince of all philosophers.' ${ }^{3}$ This man deserves this noble description because he provides "the best plane of immanence ... the purest, the one that does not hand itself over to the transcendent, the one that inspires the fewest illusions, bad

${ }^{1}$ Cf. Gilles Deleuze, Spinoza: Practical Philosophy, trans. by Robert Hurley (San Francisco: City Light Books, 1988), 3.

${ }^{2}$ Ibid.

${ }^{3}$ Gilles Deleuze, Expressionism in Philosophy: Spinoza, trans. by Martin Joughin (New York: Zone Books, 1992), 11.

(c) 2017 Raniel SM. Reyes

http://www.kritike.org/journal/issue 20/reyes june2017.pdf

ISSN 1908-7330

$(c c)$ BY-NC-ND 


\section{THE REVOLUTIONARY SPINOZA}

feelings, and erroneous perceptions." ${ }^{4}$ To be specific, Deleuze finds in Spinoza the radical possibility of thinking and social existence emancipated from the fetters of the State. ${ }^{5}$ This can be perceived in the A Theologico-Political Treatise, where Spinoza formulates a philosophy that critically appraises the degenerate status quo. ${ }^{6}$ For instance, he questions his fellowmen why they choose their own enslavement and perceive it as freedom-a convergent theme problematized by Deleuze and Guattari in the entire Anti-Oedipus: Capitalism and Schizophrenia. ${ }^{7}$

Spinoza's audacity should not surprise us when Negri, in Savage Anomaly: the Power of Spinoza's Metaphysics and Politics, considers him as the anomaly of the century, "an anomaly of victorious materialism, of the ontology of being that always moves forward and that by constituting itself poses the ideal possibility for revolutionizing the world." 8 Albeit life can achieve a certain degree of optimization within a democratic or a liberal society, the philosopher must not limit himself or herself with it. Following Deleuze, "the philosopher solicits forces in thought that elude obedience as well as blame, and fashions the image of a life beyond good and evil, a rigorous innocence without merit or culpability. The philosopher can reside in various states, he can frequent various milieus, but he does so in the manner of a hermit, a shadow, a traveler." ${ }^{9}$ In this manner, dissonance and nomadism are legitimized as cardinal virtues in Spinozist philosophy. In the other works of Deleuze, these aforementioned virtues are analogously conceptualized. In Nietzsche and Philosophy, he conceives the virtues of affirmation and revaluation as the new values in the tragic world of Dionysus that is liberated from the fetters of Christianity (transcendental philosophy). ${ }^{10}$

A life characterized by fecundity and dynamism is termed by Spinoza as Nature. This major Spinozist thesis hinges on the idea of a single

\footnotetext{
${ }^{4}$ Gilles Deleuze and Felix Guattari, What is Philosophy?, trans. by Hugh Tomlinson and Graham Burchell (New York: Columbia University Press, 1994), 60.

${ }^{5}$ If ever he speaks about the perils of a revolution, it is about the perdition and disappointments of Cromwell's revolution and the possible coup d'etat by the House of Orange. In his words, "During these periods, 'revolutionary' ideology is permeated with theology and is often, as with the Calvinist party, in the service of a politics of reaction." Deleuze, Spinoza: Practical Philosophy, 9.

${ }^{6}$ Cf. Baruch Spinoza, A Theologico-Political Treatise in Works of Spinoza, vol. 1, trans. by R. Elwes (New York: Dover Publications, 1951), 250.

${ }^{7}$ Cf. Gilles Deleuze and Felix Guattari, Anti-Oedipus: Capitalism and Schizophrenia, trans. by Robert Hurley, Mark Seem, and Helen R. Lane (Minneapolis: University of Minnesota Press, 1983).

${ }^{8}$ Cf. Antonio Negri, The Savage Anomaly: The Power of Spinoza's Metaphysics and Politics (Minneapolis and Oxford: University of Minnesota Press, 1991), xvi.

${ }^{9}$ Deleuze, Spinoza: Practical Philosophy, 4.

${ }^{10}$ Cf. Gilles Deleuze, Nietzsche and Philosophy, trans. by Hugh Tomlinson (New York: Columbia University Press, 1983), 14-17.
}

(c) 2017 Raniel SM. Reyes

http://www.kritike.org/journal/issue 20/reyes june2017.pdf

ISSN 1908-7330

(c) $)$ BY-NC-ND 
substance bearing inestimable modes of singularities and attributes, in the same manner that it conditions the possibility of a plethora of becomings. ${ }^{11}$ In Ethics, Nature is understood as substance and cause (Natura naturans), and as effect and mode (Natura naturata). ${ }^{12}$ These two conditions allow us to talk about Nature in general. Naturalism, in the context of Spinozism, satisfies the univocity of attributes (where the attributes in the same form constitute the essence of God as naturing nature and contain essences of modes as natured nature); the univocity of the cause (where the cause of all things is affirmed of God as the genesis of natured nature in the same sense that he caused himself); and the univocity of modality (where necessity qualifies both the order of natured nature, as well as naturing nature's organization). ${ }^{13}$

The philosopher John Duns Scotus shares with Spinoza the fundamental belief that Being is univocal. Their ontological theorization of univocity is a valiant antipathy directed to a long history of western philosophical tradition systemically influenced by Platonic metaphysics or transcendental philosophy. What Deleuze derives from Scotus is the idea that it is only in univocity where genuine difference becomes possible. Deleuze explains in Difference and Repetition that, "The essential in univocity is not that Being is said in a single and same sense, but that it is said, in a single time and same sense, of all individuating differences or intrinsic modalities. Being is the same for all these modalities, but these modalities are not the same .... The essence of univocal being is to include individuating differences, while these differences do not have the same essence and do not change the essence of being." 14 Meanwhile, Spinoza treats univocal being with pure affirmation, instead of neutrality or indifference, as it is "identical with unique, universal and infinite substance." 15 If transcendental philosophy erects a $38^{\text {th }}$ parallel between mind and matter, for instance, then they metamorphose as attributes belonging to a single substance in the milieu of Spinozist univocity.

Spinozist univocity plays a very important role in Deleuze's formulation of the concept of immanence. Deleuze's philosophy of immanence is indispensably influenced by Spinoza's ontology that is not merely materialist, but also pantheistic, atheistic, yet ethical in nature. Spinozist ontology is pantheistic because Nature and God are comprehended as identically responsible for the productions of all affections. It is atheistic since it denunciates consciousness, values and sad passions, and more

\footnotetext{
${ }^{11}$ Cf. Deleuze, Spinoza: Practical Philosophy, 7.

${ }^{12}$ Cf. Baruch Spinoza, Ethics in A Spinoza Reader, ed. and trans. by Edwin Curley (New Jersey: Princeton University Press, 1994), 57.

${ }^{13}$ Deleuze, Spinoza: Practical Philosophy, 92-93.

${ }^{14}$ Gilles Deleuze, Difference and Repetition, trans. by Paul Patton (New York: Columbia University Press, 1994), 36.

${ }^{15}$ Ibid., 40.
}

(c) 2017 Raniel SM. Reyes

http://www.kritike.org/journal/issue 20/reyes june2017.pdf

ISSN 1908-7330 
importantly, a Creator outside being. Lastly, it is ethical because Spinoza, in Deleuze's perception, opens us to a life of pure immanence: “We will speak of pure immanence that it is A LIFE, and nothing else. It is not immanence to life, but the immanent that is in nothing is itself a life. A life is the immanence of immanence." 16 Under a life of univocity, the world turns into a democratized plane for all beings. Outside the Spinozist universe, the philosophical theme of immanence parallels with Bergson's notion of the Whole (as constitutive of monistic time, infinite durations, and pure virtuality) and Nietzsche's tragic world of Dionysus. ${ }^{17}$ For the former, the Whole is a plane where space and duration, perception and memory, the past and the present, recollection-memory and contraction-memory are understood in the yardstick of virtual coexistence. ${ }^{18}$ For the latter, the dedeified world is a world of pure becoming whose governing principle is the Eternal Return. ${ }^{19}$

Deleuze explains that the title of the last chapter, "Spinoza and Us" of Spinoza: Practical Philosophy, means being in "the middle of Spinoza." 20 Precedent to Deleuze's characterization of micro-politics as a "politics of the middle," is the recommendation that the most profound way to comprehend Spinozism is by way of the middle. In his words:

Generally one begins with the first principle of a philosopher. But what counts is also the third, the fourth, or the fifth principle. Everyone knows the first principle of Spinoza: one substance for all the attributes. But we also know the third, fourth or fifth principle: one Nature for all bodies, one Nature for all individuals, a Nature

\footnotetext{
${ }^{16}$ Gilles Deleuze, Pure Immanence: Essays on A Life, trans. by Anne Boyman (New York: Zone Books, 2005), 27.

${ }_{17}$ Cf. Gilles Deleuze, Bergsonism, trans. by Hugh Tomlinson and Barbara Habberjam (New York: Zone Books, 1988), 93. Like Spinoza, Bergson's immanent philosophy offers a critique of State philosophy. See Brian Massumi, "Translator's Foreword: Pleasure of Philosophy," in Gilles Deleuze and Felix Guattari, A Thousand Plateaus: Capitalism and Schizophrenia, trans. by Brian Massumi (Minneapolis: University of Minnesota Press, 1987), ix.

${ }^{18}$ Cf. Ibid., 91

${ }^{19}$ Deleuze defines the Eternal Return as "the being of that which becomes. It is the being of becoming itself, the being which is affirmed in becoming." Deleuze, Nietzsche and Philosophy, 48. A similar description can be seen in Difference and Repetition: "The eternal return is not the effect of the identical upon a world to become similar; it is not an external order imposed upon chaos of the world; on the contrary, the eternal return is the internal identity of the world and of chaos." Deleuze, Difference and Repetition, 299.

${ }^{20}$ Deleuze, Spinoza: Practical Philosophy, 122. Being at the middle of Spinoza is analogous to the Humean project of becoming-multiple. In Dialogues, Deleuze and Parnet characterize Hume's empiricist philosophy as a practical philosophy of "becoming-multiple, instead of beingone, a being-whole or being as subject." Gilles Deleuze and Claire Parnet, Dialogues, trans. by Hugh Tomlinson and Barbara Habberjam (New York: Columbia University Press, 1987), 132.
}

(c) 2017 Raniel SM. Reyes

http://www.kritike.org/journal/issue 20/reyes june2017.pdf

ISSN 1908-7330

(cc) BY-NC-ND 
that is itself an individual varying in an infinite number of ways. ${ }^{21}$

A philosophy of the middle exhibits Deleuze's radical reconstruction of Spinoza's monism. It is not simply a conservative asseveration of a single substance, but rather a diagramming of a common plane of immanence where all bodies, minds, and individuals are situated..$^{22}$ In this realm, the "plane of organization or transcendence" and the "plane of immanence," are not perceived as dual opposites, but of a multiplicity of dimensions, lines, and directions in an assemblage. ${ }^{23}$ The former's legitimacy emanates from a transcendental sphere-a divine plan in god's mind and an evolution in a society's organization of power. ${ }^{24}$ The plane of organization always involves genetic or structural subjectivity formations, which can only be inferred from what it gives. ${ }^{25}$ The plane of immanence, on the other hand, comprises of innumerable collectivities, individuals, and bodies, subjected to multi-faceted combinations or relations. Deleuze thinks that the plane of immanence is Nature's plane of composition.

In this regard, instilling oneself in the middle of Spinoza implies two things. First, it entails Spinoza, including Deleuze's underlying belief that thought is devoid of any primordial origin whatsoever, but only of outside by which it is connected; and, second, being in Spinoza' middle means situating oneself in the immanent modal plane. And since this plane is not founded on any metaphysical principle, then relations forces and bodies are defined in accordance to their material performances and variations, i.e. on their ability to affect and be affected by other bodies whether by virtue of cultivation or decomposition. The ceaseless transformation of the plane of immanence, in Gaten's view, "fragments the normative work of the plane of organization which, in turn, refolds and re-expresses this undoing by attempting to block and contain in molar forms the mobility and dynamism of the molecular." 26

"Immanence" is a very significant and overarching term in the entire Deleuzian canon. ${ }^{27}$ Deleuze's theorization of immanence, greatly influenced

${ }^{21}$ Deleuze, Spinoza: Practical Philosophy, 122.

22 Ibid.

${ }^{23}$ Cf. Deleuze and Parnet, Dialogues, 132-133; Cf. Moira Gatens, "Through a Spinozist Lens: Ethology, Difference, Power," in Deleuze: A Critical Reader, ed. by Paul Patton (Oxford: Blackwell Publishers, 1996), 165.

${ }^{24}$ Cf. Deleuze, Spinoza: Practical Philosophy, 128.

${ }^{25}$ Cf. Ibid.

${ }^{26}$ Gatens, "Through a Spinozist Lens: Ethology, Difference, Power," 165.

${ }^{27}$ Immanence in the Deleuzian philosophy is interchangeably used with "empiricism." In relation to this, Vincent Descombes in Modern French Philosophy describes the project of Deleuze as a quest for a transcendental empiricism. Cf. Gilles Deleuze, Empiricism and Subjectivity: An 


\section{THE REVOLUTIONARY SPINOZA}

by Spinoza's nature, is perceivable in his anti-juridical position against State philosophy. In Savage Anomaly, Negri ingeniously describes Spinoza's relationship with Deleuze as an "encounter with continuity," which likewise presupposes not only Deleuze's, but also Negri's profound indebtedness to the anti-juridical philosophy of Spinoza. ${ }^{28}$ The anti-juridical philosophy of Deleuze is an appendage to his over-all criticism of transcendental moralitythe morality responsible for the marginalization of the materiality of life and the creative potentialities of the body. Spinoza is a critical witness to this type of morality prevalent in Western scholarship, especially in the juridical tradition. In essence, juridical scholarship implies that "forces have an individual or particular origins; that they must be socialized to engender relation that adequately correspond to them; that there is a mediation of Power; and that the horizon is inseparable from a crisis, war or antagonism for which Power is presented as the solution, but the 'antagonistic solution.'"' 29

Before Kant, Hobbes is one of the foremost prophets of transcendentalism latently manifested in his social contract theory. For Hobbes, the Power of the State is determined by its power of legitimization. The State configures its legitimacy as a metaphysical guarantor based on the rational individuals' will (Leviathan). On the contrary, Spinoza asserts that an individual's natural right refers merely to his/her act of self-preservation (conatus). Contra Hobbes, he argues that an individual's conatus and man's rights are not transferrable to another, especially to a metaphysical authority. ${ }^{30}$ Similarly, in the Hobbesian territory, the only thing common to each individual is one's desire for self-preservation, especially when a common object of interest exists. In this sense, it appears that the State's power is merely shaped by its actual capability or desire of self-preservation that thereby voids the idea of arriving at a collective rationality, which is nothing but a whimsical idea.

However, in order to distantiate Spinoza from the accusation of anarchism, it must be made clear that he does not categorically negate any effort of the State to harmonize individual relationships in the form of ethical standards and public policies. What he opposes is the State's project of

Essay on Hume's Theory of Human Nature, trans. by Constantin Boundas (New York: Columbia University Press, 1990), 3. French poststructuralist thinkers, in the likes of Jacques Derrida, join Deleuze in his search for a novel foundation divergent from the transcendental plane, characterized by difference, constellations, and dislocations. Jacques Derrida, Writing and Difference, trans. by Alan Bass (Chicago: University of Chicago Press, 1978), 151.

${ }_{28}$ See Negri, The Savage Anomaly, 3-21.

29 Aurelia Armstrong, "Some Reflections on Deleuze's Spinoza: Compositions and Agency," in Deleuze and Philosophy: The Difference Engineer, ed. by Keith Ansell-Pearson (London and New York: Routledge, 1997); Deleuze, Preface to Negri, Savage Anomaly.

${ }^{30}$ Cf. Spinoza, A Theologico-Political Treatise, 214.

(c) 2017 Raniel SM. Reyes

http://www.kritike.org/journal/issue 20/reyes june2017.pdf

ISSN 1908-7330

(cc) BY-NC-ND 
advancing its totalizing and narcissistic interests using the ploy of achieving communal cohesion under the authority of the Leviathan. ${ }^{31}$ In other words, he only repudiates all transcendental configurations that overlay on the initiative of the multiplicity of a transcendent synthesis. ${ }^{32}$ Against the various juridical mystification of the State, he formulates a kind of immanent horizon characterized by active forces, relations, and possibilities. Spinoza describes the state as a product of a purely natural process, in consonance with the cultivation of natural right and personal life. In this vein, the state's genealogical configuration is nothing but a product of secularized procedures and struggles, and not of metaphysical or divine-laden processes. For example, ethical relation and difference between bodies in the State are defined not in accordance to an overarching transcendental principle. Rather, the relation and distinction between bodies "relates to the kind of affections that determine our conatus." 33 In the study of ethology, the behavior of bodies in the plane of immanence is governed by the power of self-preservation. However, the numerous bodies' perseverance entails a necessary encounter with other bodies. It can be argued, therefore, that the aptitude and movement of bodies may vary depending on the quality and quantity of other bodies they associate with. Likewise, this creative encounter posits the idea that even the power of self-preservation is not immune from the affections from the exterior.

This characterization inspired Spinoza to re-configure democracy under the rubric of materialism and production-the politics of the multitude. ${ }^{34}$ This mature phase in the philosophy of Spinoza, from the $A$ Theologico-Political Treatise onwards, constitutes a radical materialism of bodies and surfaces where praxis constitutes being as an incessant reconstruction by human praxis. ${ }^{35}$

\section{Ethology: An Immanent Philosophy of Agency}

Spinoza's materialist ontology is an ethology or an ethics situated in the plane of immanence. In this plane, there is only a single immanent substance: the human individual-a mode of nature's attributes and a

${ }^{31}$ For Deleuze, compact is one of the states of value judgments where individuals attempt to unite with parallel bodies. Cf. Deleuze, Expressionism in Philosophy: Spinoza, 257; Cf. Armstrong, "Some Reflections on Deleuze's Spinoza: Compositions and Agency," 144.

32 Negri, The Savage Anomaly, 130.

${ }^{33}$ Deleuze, Expressionism in Philosophy: Spinoza, 261. In Ethics, Spinoza writes, "Each thing, as far as it can by its own power, strives to persevere in its being." Spinoza, Ethics, 159.

${ }^{34}$ Cf. Ibid., xviii.

${ }^{35}$ Cf. Ibid., xvii. 


\section{THE REVOLUTIONARY SPINOZA}

fragment of a protean and interrelated whole. But it is important to accentuate that in this plane, the individual does not enjoy a privileged position in relation to other entities, in the same manner that subjectivity is not limited to the realm of rationality. Univocity of being promotes an ontological democracy, where everything metamorphoses into bodies, whose value is gauged not according to one's rational and discursive capacities, but on speeds, as well as the ability to affect and to be affected. ${ }^{36}$ The same description is found in Deleuze and Guattari's collaborative work, $A$ Thousand Plateaus, where they claim that in the study of ethology, bodies are not defined according to some logico-biological categories such as genus and specie: "It is no longer a question of organs and functions, and of a transcendent Plane that can preside over that organization only by means of analogical relations and types of divergent development. It is a question not of organization, but of composition; not of development or differentiation but of movement and rest, speed and slowness." 37 Similarly in Anti-Oedipus, they opine that ethology can be comprehended in the realm of desiringproduction. In this realm, a dichotomy does not exist between man and nature, or the human and the nonhuman. Instead of perceiving them as binary opposites, they are already perceived as part of a whole process of life: "Not man as the king of creation, but rather as the being who is in intimate contact with the profound life of all forms or all types of being, who is responsible for even the stars and animal life, and who ceaselessly plugs an organ-machine into an energy-machine, a tree into his body, a breast into his mouth, the sun into his asshole." 38

Furthermore, Deleuze explains how the concept immanence in the Spinozist universe achieves an ontological status. Substance, attributes, and the modes are understood in relation to expression, rather than to a transcendent organization of emanation. ${ }^{39}$ Substance is not privileged in relation to any attributes, in the same fashion that no attribute is superior to another. An attribute expresses a particular essence. As Deleuze argues, "The essence that is expressed is an unlimited, infinite quality. The expressive

${ }^{36}$ Cf. Deleuze, Spinoza: Practical Philosophy, 125.

${ }^{37}$ Deleuze and Guattari, A Thousand Plateaus, 255; Cf. Deleuze, Difference and Repetition, 40.

${ }^{38}$ Deleuze and Guattari, Anti-Oedipus, 5.

${ }^{39}$ Cf. Miguel de Beistegui, Immanence - Deleuze and Philosophy (Edinburgh: Edinburgh University Press, 2010), 47. The term "expressionism" in Deleuze's Expressionism in Philosophy: Spinoza originally bears an artistic French and German genealogy seen in the works of Artaud and Bacon. As Macherey opines, expressionism opposes the "subtle distribution of impressions over a horizontal plane on which they appear to float weightlessly ... the vertical force of expression revealed in the violence of utterances and gestures that present through more or less systematically organized distortions the most strident aspects of reality and life." Pierre Macherey, "The Encounter with Spinoza," in Deleuze: A Critical Reader, ed. by Paul Patton, 143.

(c) 2017 Raniel SM. Reyes

http://www.kritike.org/journal/issue 20/reyes june2017.pdf

ISSN 1908-7330

(cc) BY-NC-ND 
attribute relates essence to substance and it is this immanent relation that the intellect grasps. All the essences, distinct in the attributes, are as one in substance, to which they are related by the attributes." 40

Meanwhile, in Expressionism in Philosophy: Spinoza, Deleuze elucidates the concept "expression" as double-edged hermeneutical device that capacitates us to interpret texts, relations, and events, not limited to the frontiers of representation, identity, linearity, and teleology. In understanding history, for instance, we must not merely interpret it as a linear progression of events towards a grand purpose or simply as a culmination of a single Unitarian concept. Neither should we reduce it into perpetual becoming. Craig Lundy's History and Becoming: Deleuze's Philosophy of Creativity offers a profound articulation of Deleuze's expressionist reading of history. He interprets Deleuze's philosophy of history as irreducible to either historicism or nomadic becoming. This novel kind of historical philosophizing does not conform to either aforementioned dualism, but operates in-between. History as historicism and nomadic becoming, Lundy writes, "will emerge in the middle to compose a productive composite or differential history/becoming." ${ }^{41}$ Expression or expressionism dismantles the logical stratification and arboreal scheme of things towards a relational and minortarian reading (or the in-between) of understanding things, on a parallel level of expression. ${ }^{42}$ At the macro-level, being a Spinozist entails embracing bare life in its concealed, unconscious, and marginal appearances in the history of philosophy: "There is a philosophy-becoming which has nothing to do with the history of philosophy and which happens through those the history of philosophy does not manage to classify." 43 Indeed, a Deleuzian notion of immanence develops as a kind of creative heterogenetic ontology that extends Spinoza's concept of expressionism by depicting how substance produces its very own modes and characteristics via a twofold process of differentiation. ${ }^{44}$

Ethology, moreover, is a philosophical perspective that does not presuppose a reality beyond the contours of life's materialities and is irreducible to the epistemological regimentations of Platonic, Cartesian, and

${ }^{40}$ Deleuze, Spinoza: Practical Philosophy, 51.

${ }^{41}$ Cf. Craig Lundy, History and Becoming: Deleuze's Philosophy of Creativity (Edinburgh: Edinburgh University Press, 2012), 9.

42 In Expressionism in Philosophy: Spinoza, Deleuze writes that, "The way Spinoza understands the notion of expression ... lies perhaps at the heart of his thought and style, and is one of the secrets of the Ethics: a two-sided book, with its continuous succession of propositions, demonstrations, and corollaries on the one hand, and its violent, broken chain of scholia on the other." Deleuze, Expressionism in Philosophy: Spinoza, 337. See also Deleuze, Spinoza: Practical Philosophy, 28-29.

${ }^{43}$ Deleuze and Parnet, Dialogues, 2.

${ }^{44}$ Cf. Beistegui, Immanence - Deleuze and Philosophy, 47. 


\section{THE REVOLUTIONARY SPINOZA}

Kantian metaphysics. ${ }^{45}$ Since metaphysics is the handmaiden of morality, Spinoza's ethology transforms as an antithetical and ontological ethics of singularities and becomings. In addition, because the locus of morality is the universal Subject or the mechanistic organism, ethology serves as a venue for a micro-politics of the subject that focuses on the fissures molded from its incessant relation to itself and to other assemblage of bodies.

Speaking of assemblage of bodies, the body assumes the position of being the new model of philosophizing in the study of ethology. In Ethics, Spinoza asserts that:

For indeed, no one has yet determined what the body can do ... from the laws of Nature alone, insofar as Nature is only considered to be corporeal, and what the body can do only if it is determined by the mind. For no one has yet come to know the structure of the body so accurately that he could explain all its functions .... This shows well enough that the body itself, simply from the laws of its own nature, can do many things which its mind wonders at. ${ }^{46}$

Spinoza's adjuration to make the body as the new model signifies its ability to surmount all our logical abstractions pertaining to it, including thought's capability to go beyond consciousness. Deleuze opines that, "there are fewer things in the mind that exceed the consciousness than there are things in the body that exceed our knowledge. So, it is by one and the same movement that we shall manage to capture the power of the body beyond the given conditions of our knowledge ... and the power of the mind beyond the given conditions of our consciousness." 47 The various powers and possibilities of the body can only be unleashed through perpetual syncretism and struggles with other bodies. This inspires Spinoza to develop the concept of agency.

The reason behind Spinoza's formulation of agency is two-fold. Historically, it seeks to revolutionize the decadent multitude of his time; and philosophically, it aspires to antagonize the traditional or transcendental notion of subjectivity that enormously shaped western philosophical thinking. His philosophy of agency critically aims to salvage the body from its marginalization in the history of western morality. Since the ancient times, the body is subordinated to the logic of the mind or consciousness. Its 2010), 261.

${ }^{45}$ Cf. Adrian Parr, ed., The Deleuze Dictionary (Edinburgh: Edinburgh University Press,

${ }^{46}$ Spinoza, Ethics, 155-156.

${ }^{47}$ Deleuze, Spinoza: Practical Philosophy, 18.

(c) 2017 Raniel SM. Reyes

http://www.kritike.org/journal/issue 20/reyes june2017.pdf

ISSN 1908-7330

(c) $\mathrm{BY}-\mathrm{NC}-\mathrm{ND}$ 
contingent attributes such as corporeality and mutability are pondered as debilities of the human condition without painstakingly exploring its great and unrepeatable potentialities. Writ large, this historico-philosophical violence depicts transcendental philosophy's supremacy over immanence in the entire western philosophical scholarship-ostensibly reflected in morality.

Spinoza's agency is integrally informed by the dynamics of materiality of life. This radical attribute influenced Deleuze's appropriation of the concept of agency as something assemblagic and collective. A Deleuzian appropriation of Spinozist agency deals the processes of collectivization that produces composition or combination of individuals with greater power and multiplicity, and individuals as modalities of these greater individuals. ${ }^{48}$ The encounter of agencies (bodies) may increase or decrease their capacities and may craft novel or degenerate constellations, affects, and intensities. Nietzsche calls this event as the experience of "chaos" within oneself that not only entails one's reflexive relation with oneself, but also the rupture of one's egoistic or transcendental-laden self as a precondition to a life of becoming. ${ }^{49}$ In the Spinozist human agency, the individual is disposed to associate (actively or passively) with other bodies, which will fortify his or her resilience. ${ }^{50}$ Following Deleuze, "we experience joy when a body encounters ours and enter into a composition with it, and sadness, when .... a body ... threatens our own coherence." ${ }^{51}$ In other words, an individual agency's mode of existence can be pondered as bad, servile, or weak, if he or she is incapacitated to exercise his or her power of acting. And it is to be considered as good, free, or rational when he or she exhibits his or her capability for being affected wherein its power of acting increases and strengthens, thus, crafting active affections and adequate ideas. ${ }^{52}$

\footnotetext{
48 Armstrong, "Some Reflections on Deleuze's Spinoza: Compositions and Agency," 50.

${ }^{49}$ Friedrich Nietzsche, Thus Spoke Zarathustra: A Book for All and None, trans. by Walter Kaufmann (Penguin Books, 1966), 17.

${ }^{50}$ In Deleuze's view, passive affections are classified as a second level effect where "the affections designate that which happens to the mode, the modifications of the mode, the effects of other modes on it." Deleuze, Spinoza: Practical Philosophy, 48.

${ }^{51}$ Ibid., 19.

${ }^{52}$ Hence, a discussion on the characteristics of ethological relations inevitably brings us back to the two fundamental questions of Spinoza's Ethics according to Deleuze, namely, "What must we do in order to be affected by a maximum of joyful passions?" and "What must we do in order to produce in ourselves active affections?" The first problem heartens us to organize relations and opportunities where bodies can be affected by a maximum quality and quantity of joyful passions. But at the end of the day, we must realize that joyful passions are not enough because the continuous production of joyful passions does not guarantee bodies' full possession of their respective powers of action. Rather than merely experiencing joyful passion, we must search for the means in order to fashion within ourselves active affections - the main point of the second problem. See Deleuze, Expressionism in Philosophy: Spinoza, 273-274.
} 


\section{THE REVOLUTIONARY SPINOZA}

Nevertheless, the complexity remains that creative and noble consequences find no guarantee and transparency in a world of immanence because there are no default attributes of the mind, body, and relations. ${ }^{53}$ Since constellation of bodies may equally foster unwanted or debased affections, Spinoza formulates the theory of common notions or compact in order to regulate or condition life-affirming encounters and possibilities. ${ }^{54}$ According to Deleuze, "When we encounter a body that agrees with our own, when we experience a joyful passive affection, we are induced to form the idea of what is common to that body and our own. ${ }^{55}$ He suggests that with the help of joyful passions, the idea of what is common to our own and the bodies external to us are created. Meaning to say, agreement or unity between two or more bodies is coextensive with utility.

When two bodies clash based on a common concern of preserving their composition and scarcity of resources, they transform into enemies. However, rather than interpreting this encounter of bodies event in a Hobbesian fashion, Deleuze approaches this problematic differently. Two or more bodies, he claims, must recognize that compact is in their rational longterm mutual self-interest. ${ }^{56}$ Gillian Howie, in Deleuze and Spinoza: Aura of Expression, lucidly summarizes Deleuze's reasons why is it that compact is in the two bodies' mutual self-interest:

First, all men have relevantly similar natures, these natures are agreeable thus each will be affected with joy in the encounter. Secondly, this means that the quantity of active passions will be increased in each individual and the individual's power of action will be increased. This is in the interest of each individual. Finally, the individual bodies unite and through this third relation compose a single body. Although each body is preserved in the new combination, the new body is 'twice as strong. ${ }^{57}$

${ }^{53}$ In Spinoza: Practical Philosophy, Deleuze asserts, "But this is only our body in its own relation, and our mind in its own relation, and the other bodies and other minds or ideas in their respective relations, and the rules according to which all these relations compound with and decompose one another; we know nothing of all this in the given order of our knowledge and our consciousness." Deleuze, Spinoza: Practical Philosophy, 19.

54 The theory of common notions is an ethical activity that seeks to organize good encounters, composing relations, forming powers, experimenting. Cf. Ibid., 19.

55 Deleuze, Expressionism in Philosophy: Spinoza, 283; Cf. Deleuze, Spinoza: Practical Philosophy, 55 .

${ }^{56}$ Cf. Ibid., 264; Cf. Gillian Howie, Deleuze and Spinoza: Aura of Expression (New York: Palgrave, 2002), 145.

${ }^{57}$ Ibid., 145-146.

(c) 2017 Raniel SM. Reyes

http://www.kritike.org/journal/issue 20/reyes june2017.pdf

ISSN 1908-7330

(c) BY-NC-ND 
Moreover, such an adequate idea of the common notion allows us to be in possession of our power of action, because "a mind that forms an adequate idea is the adequate cause of the ideas that follow from it." 58 Accordingly, a certain kind of "feeling which is a passion ceases to be a passion as soon as we form a clear and [adequate] idea of it." 59 In the wider context of political relations, ethology seeks to render a basis from which to rethink the political in a non-hegemonic or non-normative way that would evade the reduction of variations or differences to relations of oppression and domination. ${ }^{60}$

The human individual, in the study of ethology, is configured along two axes: kinetic and dynamic. In the former, the individual is perceived as composite of other bodies and whose attribute is relational (speed and slowness) in nature. In the latter, the individual is seen as a gradation of power in the sea of other bodies that can affect and be affected by that individual. ${ }^{61}$ Similarly, the body's identity is conceived as an open-ended reality because of its unceasing dialogue with the exterior world. Since the body is an immanent reality, its internal configurations depend on its aptitude to affect and be affected by others. According to Deleuze, "a body's structure is the composition of its relation. What a body can do is the nature and the limits of its power to be affected." 62

The individual in the Spinozist philosophy is understood as the complex organization of the existing mode in any attribute. ${ }^{63}$ This mode bears a singular essence, which is likewise a degree of power. Albeit characterized by singularity, the individual's essence is relational in nature. Deleuze elucidates the potentialities of the body in terms of what Spinoza calls as modes. As a kind of modality, the body is characterized by an essence perceivable as a gradation of power containing various immanent parts. ${ }^{64}$ The single substance's expression through modes only bears these parts by virtue of its capability to affect and be affected in a particular relation. ${ }^{65}$ Because the modes are off-springs of endless relations, then it would simply diminish

${ }^{58}$ Deleuze, Expressionism in Philosophy: Spinoza, 283.

${ }^{59}$ Ibid.

${ }^{60}$ Cf. Rosi Braidotti, "Towards a New Nomadism: Feminist Deleuzian Tracks; or, Metaphysics and Metabolism," in Gilles Deleuze and the Theater of Philosophy, ed. by Constantine Boundas and Dorothea Olkowski (New York: Columbia University Press, 1994).

${ }^{61}$ Ibid., 27; Cf. Gatens, “Through a Spinozist Lens: Ethology, Difference, Power," 167.

62 Deleuze, Expressionism in Philosophy: Spinoza, 92.

${ }^{63}$ Cf. Deleuze, Spinoza: Practical Philosophy, 76.

${ }^{64}$ Deleuze, Spinoza: Practical Philosophy, 76.

${ }^{65} \mathrm{Ibid}$; Cf. Abigail Lowe, Intersections in Immanence: Spinoza, Deleuze, Negri (M.A. Thesis, Lincoln, Nebraska: University of Nebraska, May 2013), 8. 


\section{THE REVOLUTIONARY SPINOZA}

when it no longer contains this ability for they are themselves active affections: "The mode passes into existence when its relation actually subsumes an infinity of extensive parts ... determined to enter into characteristic relation ... through the operation of an external determinism. The mode ceases to exist when its parts are determined from without to enter into a different relation, which is not compatible with the former one." 66 In short, the individual is composed of unlimited extensive parts. But these parts are not constitutive of individual essences in themselves because they are organized only on the basis of extensive determinism. ${ }^{67}$ Despite the twin possibilities of a body to decompose or strengthen itself after a certain encounter with another, the fact remains that in every relation, there exists an eternal truth, where "Nature in its entirety is conceived as an Individual that composes all relations and possesses all the sets of intensive parts with their different degrees." 68

At this point, I must underscore that despite Spinoza's radicalization of metaphysics, he does not espouse the privileging of the body over the mind or consciousness. His repudiation of the primacy of the mind over the body does not want to fall into a vicious circle of privileging the body over the mind just to give slavish justice to the former. Deleuze escapes this philosophical quicksand by introducing the concept of "parallelism." He opines that parallelism "does not consist merely in denying any real causality between the mind and the body, it disallows any primacy of one over the other." 69 Ethics bluntly invalidates the conventional belief that the body's activities and attributes are merely dependent on the workings of the mind. Deleuze argues that "what is an action in the mind is necessarily an action in the body as well, and what is passion in the body is necessarily a passion in the mind. There is no primacy of one over the other." 70 His notion of parallelism demonstrates that the body exceeds the epistemic registers that we have of it, in the same fashion that thought exceeds the consciousness that we have of it. This is the reason why Deleuze suggests that the traditional notion of the philosophy of consciousness must re-think its hubris and blindness in relation to the body. Consciousness is caused by determinate affections - the consciousness of the conatus on the striving of things and man to preserve its being is produced by affection towards joy or sadness, "and since the affections," Deleuze explicates, "are not separable from a movement by which they cause us to go to a greater or lesser (joy and sadness), depending on whether the thing encountered enters into a composition with us, or on the contrary tends to

\footnotetext{
${ }^{66}$ Deleuze, Spinoza, Practical Philosophy, 76.

${ }^{67}$ Cf. Ibid., 77.

${ }^{68}$ Ibid.

${ }^{69} \mathrm{Ibid} ., 18$.

${ }^{70}$ Ibid.
}

(c) 2017 Raniel SM. Reyes

http://www.kritike.org/journal/issue 20/reyes june2017.pdf

ISSN 1908-7330

(cc) BY-NC-ND 
decompose us, consciousness appears as the continual awareness of this passage from greater to lesser, or from lesser to greater, as a witness of the variations and determinations of the conatus functioning in relation to other bodies or ideas." ${ }^{71}$ As a footnote to the aforementioned explanation, Deleuze states that "One seeks to acquire a knowledge of the powers of the body in order to discover in a parallel fashion, the powers of the mind that elude consciousness, and thus to be able to compare the powers." ${ }^{72}$ Thus, the principle of parallelism adheres to the univocity of being and aims for the discovery of an "unconscious of thought just as profound as the unknown of the body." 73

\section{Politics of Desire as a Cartography of a Revolution-to-come}

At this juncture, I deem it necessary to construe the relationship between Spinoza's immanent ethics and Deleuze's theory of desire. In the domain of individual agency, desire as conatus illustrates the individual as determined by its power to be both the subject and object of affection "provided that we do not separate essence from action, a conatus can be comprehended as the essence of a being or its degree of power. Actions themselves constitute a person's affirmation of life and his will to exist." 74 In Deleuze's mature writings, the body (as conatus) becomes constitutive of various desiring-machines. Desiring-machines are parts which are unrelated to any whole connected to other desiring-machines, some within body, some in the natural and the social world. ${ }^{75}$ Contrary to conventional psychoanalysis' devaluation of desire, Deleuze and Guattari describe it is a revolutionary force and social process of experimentation capable in crafting connections and nomadic subjects that defy Oedipalization.

At the macro-level, Deleuze and Guattari stress in Anti-Oedipus that desire or desiring-production cannot be divorced from socio-political productions. ${ }^{76}$ This gives merit to Smith's recommendation in transfiguring the relation between Spinoza's ethics to Deleuze's theory of desire into a political concern. If the philosophy of transcendence symbolizes impotence, degeneration, and enslavement, then a Deleuzian ethics would investigate and analyze the conditions that engender people to desire transcendence or

${ }^{71}$ Deleuze, Spinoza: Practical Philosophy, 21.

72 Ibid., 18.

${ }^{73}$ Ibid., 19

${ }^{74}$ Parr, ed., The Deleuze Dictionary, 266.

${ }^{75}$ Cf. Ronald Bogue, Deleuze and Guattari (London and New York: Routledge, 1989), 91; Cf. Deleuze and Guattari, Anti-Oedipus, 7.

${ }^{76}$ Cf. Deleuze and Guattari, Anti-Oedipus, 68. 


\section{THE REVOLUTIONARY SPINOZA}

oppression. The book Anti-Oedipus, as a philosophical product of the 1968 student protest, seeks to answer this political problem. In Foucault's Preface to the aforesaid book, he mentions three adversaries of Anti-Oedipus. Among the three, he asserts that the most dangerous enemy is Fascism: "Not only historical fascism (Hitler and Mussolini) ... but also the fascism in us all, in our heads and in our every day, the fascism that causes us to love power, to desire the very thing that dominates us." 77 The desire for transcendence found in Deleuze's early literatures transfigures into the desire for fascism or domination in his mature writings. Based on the student revolt's sociohistorical context, Anti-Oedipus actualizes as their critique of the French people's herd instinct or desire to be exploited, especially in the post-1968 era. ${ }^{78}$ This enables them to conceptualize their immanent ethical theory or politics of desire as an antagonism against all reductive psychoanalytic and socio-political analyses that remain configured under the principle of transcendence or Oedipality, towards the multiplicity of desire.

Deleuze and Guattari's politics of desire is collective and assemblagic-a micro-politics indispensably indebted to Spinoza's ethology. Despite Spinoza and Deleuze's close affinity with Nietzsche's anti-nihilist philosophy, Anti-Oedipus does not epitomize solitary existence. As Mark Seem elucidates in his Introduction to Anti-Oedipus:

Anti-Oedipus is not the superman .... Where Nietzsche grew progressively more isolated to the point of madness, Deleuze and Guattari call for actions and passions of a collective nature, here and now. Madness is a radical break from power in the form of a disconnection. Militancy, in Deleuze and Guattari's framework, would learn from madness but then move beyond it, beyond disconnections and deterritorializations, to ever new connections. A politics of desire would see loneliness and depression as the first things to go. Such is the anti-oedipal strategy: if man is connected to the machines of the universe, if he is in tune with his desires, if he is "anchored," "he ceases to worry about the fitness of things, about the behavior of his

77 Ibid., xii.

${ }^{78}$ In A Thousand Plateaus, Deleuze and Guattari write, "For many French intellectuals, the hyperactivism of post-May gave way to a mid-seventies slump, then a return to religion or political conservatism in a foreshadowing of the Reagan eighties." Deleuze \& Guattari, $A$ Thousand Plateaus, xi.

(c) 2017 Raniel SM. Reyes

http://www.kritike.org/journal/issue 20/reyes june2017.pdf

ISSN 1908-7330

(c) ) BY-NC-ND 
fellow-men, about right or wrong and justice and injustice. ${ }^{79}$

Deleuze and Guattari's positive theorization of desire is an integral factor in the conceptualization of the principle of "schizoanalysis." Its primary goal is to radically penetrate and dismantle the various segmentarized concepts, zones, and relations already Oedipalized by fascism or in today's time, by advanced capitalism. The task of schizoanalysis, they assert, "goes by way of destruction-a whole scouring of the unconscious, a complete curettage. Destroy Oedipus, the illusion of the ego, the puppet of the superego, guilt, the law, castration." 80 More importantly, it aspires to search for the unscathed deterritorialized constellations of desire or the "flows that have not been reduced to the Oedipal codes and neuroticized territorialities, the desiring-machines that escape such codes as lines of escape leading elsewhere." 81 In other words, schizoanalysis aims at emancipating desire from being totalized by manifold and multifaceted expressions of fascism or Oedipus. They believe that schizoanalysing desire can translate into a radical politics that can instigate contemporary individuals and collectivities to formulate multiple constellations, as well as to become dynamic conduits of forces.

The politics of desire is a micro-politics. Briefly, Deleuzian micropolitics composes of three intersecting lines, namely: the segmented, supple, and the abstract line. The first line, rigid segmentarity, illustrates our binary, linear, and circular condition in the society. ${ }^{82}$ The second, the molecular line, depicts supple segmentarity, since they are contextualized, localized, and web-like. Deleuze and Parnet claim that molecular lines are the cracks between segmentarities or minortarian fluxes with thresholds capable of fashioning rhizomatic becomings and micro-becomings. ${ }^{83}$ Lastly, the third line is called the abstract line. It is a line capable of escaping segmentarities and thresholds toward unforeseeable destinations and nomadic intensities. The last line is the line of abstract detachment and absolute becoming or deterritorialization. In sum, the three lines transverse each other across all organizations, groups, and individuals.

Specifically, micro-politics is a quest for the nomad or nomadic line that would spawn genuine and revolutionary transformation. When the second line metamorphoses as the overarching principle of politics,

${ }^{79}$ Mark Seem, Introduction to Deleuze and Guattari, Anti-Oedipus, xxv.

${ }^{80} \mathrm{Ibid} ., 311$

${ }^{81}$ Ibid., xii.

${ }^{82}$ Cf. Deleuze and Guattari, A Thousand Plateaus, 209; Cf. Deleuze and Parnet, Dialogues, 124.

${ }^{83}$ Cf. Deleuze and Parnet, Dialogues, 124.

(C) 2017 Raniel SM. Reyes

http://www.kritike.org/journal/issue 20/reyes june2017.pdf

ISSN 1908-7330

(cc) BY-NC-ND 


\section{THE REVOLUTIONARY SPINOZA}

instability is of high possibility. Of course, it cannot also be the first line because segmentarity or segmentarized politics is the fortress of State philosophy - the nomad's nemesis. Does this entail then that the third line, the abstract line, is the nomadic line? ${ }^{84}$ In $A$ Thousand Plateaus, Deleuze and Guattari opine that "from the viewpoint of micro-politics, a society is defined by its line of flight, which are molecular." 85 To avoid further confusion, we must refer back to our primary characterization of the nomadic line as the creative and radical symbol of transformation. In this manner, it appears that it would be more suitable to delegate the nomad in the perpetually shifting and amorphous space in-between the striated and the supple lines. ${ }^{86}$ Micropolitics rejects neither the first nor the second line; it stays in-between them. Thus, micro-politics operates in-between the actualization of incessant transformation, polysemy, and fluidity, as well as the creation of organizations and collectivities, towards a mapping of a people and worldto-come.

\section{Conclusion}

Deleuze and Guattari's politics of desire is vitally inspired by Spinoza's ethology. Ethology is not only an evaluative, but also a selective principle - a cartography. In this sense, individual agencies and collectivities are diagrammed in the plane of immanence, in such a manner that "a body is defined only by a longitude and a latitude: in other words, the sum total of the material elements belonging to it under given relations of movement and rest, speed and slowness (longitude); the sum total of the intensive affects it is capable of at a given power or degree of potential (latitude)." ${ }^{87}$ A Deleuzian cartography diagnoses the composition of an individual and collective bodies through their extensive and intensive abilities, as well as their motion and power of affects. Since bodies are a composite of many other bodies, which in turn consist of other bodies, they may constitute the extensive parts of broader socio-political assemblages, which likewise have their respective characteristic intensive attributes. ${ }^{88}$ In short, Deleuze's cartography selects

\footnotetext{
${ }^{84}$ In The Logic of Sense, the nomads are deemed as the pure abstract line that comes 'from the east.' Gilles Deleuze, The Logic of Sense, ed. by Constantine Boundas, trans. by Mark Lester with Charles Stivale (London: Continuum, 1990), 129; Craig Lundy, "Who are Our Nomads Today?: Deleuze's Political Ontology and the Revolutionary Problematic," in Deleuze Studies, 7:2 (2013): 240

85 Deleuze and Guattari, A Thousand Plateaus, 216. Moreover, in the section, "Many Politics" of Dialogues, Deleuze and Parnet appear to interchangeably use the molecular (supple) and the abstract line or line of flight. Cf. Deleuze and Guattari, Dialogues, 130-4, 141-2.

${ }^{86}$ Lundy, "Who are our Nomads Today?," 243.

${ }^{87}$ Deleuze and Guattari, A Thousand Plateaus, 260.

${ }^{88}$ Cf. Gatens, "Through a Spinozist Lens: Ethology, Difference, Power," 168.
} 
bodies (individual, collective, political, aesthetic, economic, revolutionary, etc.) and diagnoses them in terms of composition and decomposition.

Deleuze's politics of desire implies a cartographic revolution. By virtue of schizoanalysis, it must similarly diagram nomadic bodies and relations whose desires escape Oedipalization. Since the plane of immanence is characterized by expressionist agonism, bodily, and assemblagic connections are always fluid. And because it is open to all kinds of constellations, vigilance must always be at work, especially when connections are disabled to foster creative lines of flight, as well as adulterated or polarized by more subtle forms of fascism. In the light of contemporary revolutionary praxis, cartography transfigures into a mapping and selection of assemblages (a la Nietzsche's philosophy of the eternal return as an ethical doctrine) or bodies across cultural, geographic, and epistemological distinctions, which are capacitated in dismantling existing relations that fossilize movements, thwarts constellations, and reifies radical action. But we should not be oblivious to the reality that in a post-control society epoch where capitalism is already axiomatic and exponentially highspeed, this task is like confronting the impossible.

Lastly, a revolution is a creative and rhizomic mapping constitutive of a differential and cultural collectivity that is bereft of any fixed essence or unitarian goal. A Deleuzian brand of revolutionary cartography is not merely a reactionary brand of resistance like the Communist Revolution. It is because it involves an epistemological rupture from our "old image of thought," as Deleuze explicates in Nietzsche and Philosophy, as well as the chaoticization of our desire and relations totalized by Oedipus. If the term "purpose" or "utopia" occupies any place in the discussion, it is in the form a differential and self-reflexive principle that would guide and empower us to incessantly create concepts capable of transforming the present. Even though there is no guarantee that these concepts will engender more freedom in the future, and that today's revolutionaries would not metamorphose as tomorrow's conservatives or oppressors, we revolutionaries must not be discouraged in untiringly laboring for a revolution-to-come. Borrowing from Deleuze and Parnet:

Instead of gambling on the eternal impossibility of the revolution, ... why not think that a new type of revolution is in the course of becoming-possible, and that all kinds of mutating, living machines conduct wars, are combined and trace out a plane of consistency, which 
undermines the plane of organization of the World and the States? ${ }^{89}$

$$
\begin{array}{r}
\text { Department of Philosophy } \\
\text { Research Center for Culture, Arts, and Humanities } \\
\text { The Graduate School } \\
\text { University of Santo Tomas, Philippines }
\end{array}
$$

\section{References}

Armstrong, Aurelia, "Some Reflections on Deleuze's Spinoza: Compositions and Agency," in Deleuze and Philosophy: The Difference Engineer, ed. by Keith Ansell-Pearson (London and New York: Routledge, 1997).

Bogue, Ronald, Deleuze and Guattari (London and New York: Routledge, 1989).

Braidotti, Rosi, "Towards a New Nomadism: Feminist Deleuzian Tracks; or, Metaphysics and Metabolism," in Deleuze, Gilles and the Theater of Philosophy, ed. by Constantine Boundas and Dorothea Olkowski (New York: Columbia University Press, 1994).

de Beistegui, Miguel, Immanence - Deleuze and Philosophy (Edinburgh: Edinburgh University Press, 2010).

Deleuze, Gilles and Claire Parnet, Dialogues, trans. by Hugh Tomlinson and Barbara Habberjam (New York: Columbia University Press, 1987).

Deleuze, Gilles and Felix Guattari, Anti-Oedipus: Capitalism and Schizophrenia, trans. by Robert Hurley, Mark Seem, and Helen R. Lane (Minneapolis: University of Minnesota Press, 1983). What is Philosophy?, trans. by Hugh Tomlinson and Graham Burchell (New York: Columbia University Press, 1994).

Deleuze, Gilles, Bergsonism, trans. by Hugh Tomlinson and Barbara Habberjam (New York: Zone Books, 1988). Difference and Repetition, trans. by Paul Patton (New York: Columbia University Press, 1994).

Deleuze, Gilles, Empiricism and Subjectivity: An Essay on Hume's Theory of Human Nature, trans. by Constantin Boundas (New York: Columbia University Press, 1990). Expressionism in Philosophy: Spinoza, trans. by Martin Joughin (New York: Zone Books, 1992). Nietzsche and Philosophy, trans. by Hugh Tomlinson (New York: Columbia University Press, 1983).

${ }^{89}$ Deleuze and Parnet, Dialogues, 147.

(c) 2017 Raniel SM. Reyes

http://www.kritike.org/journal/issue 20/reyes june2017.pdf

ISSN 1908-7330

(c) $)$ BY-NC-ND 
Pure Immanence: Essays on A Life, trans. by Anne Boyman (New York: Zone Books, 2005).

Spinoza: Practical Philosophy, trans. by Robert Hurley (San Francisco: City Light Books, 1988).

The Logic of Sense, ed. by Constantine Boundas, trans. by Mark Lester with Charles Stivale (London: Continuum, 1990).

Derrida, Jacques, Writing and Difference, trans. by Alan Bass (Chicago: University of Chicago Press, 1978).

Gatens, Moira, "Through a Spinozist Lens: Ethology, Difference, Power," in Deleuze: A Critical Reader, ed. by Paul Patton (Oxford: Blackwell Publishers, 1996).

Howie, Gillian, Deleuze and Spinoza: Aura of Expression (New York: Palgrave, 2002).

Lowe, Abigail, Intersections in Immanence: Spinoza, Deleuze, Negri (M.A. Thesis, Lincoln, Nebraska: University of Nebraska, May 2013),

Lundy, Craig, History and Becoming: Deleuze's Philosophy of Creativity (Edinburgh: Edinburgh University Press, 2012).

Lundy, Craig, “Who are Our Nomads Today?: Deleuze's Political Ontology and the Revolutionary Problematic," in Deleuze Studies, 7:2 (2013).

Macherey, Pierre, "The Encounter with Spinoza," in Deleuze: A Critical Reader, ed. by Paul Patton (Oxford: Blackwell Publishers, 1996).

Massumi, Brian, "Translator's Foreword: Pleasure of Philosophy," in Deleuze, Gilles and Felix Guattari, A Thousand Plateaus: Capitalism and Schizophrenia, trans. by Brian Massumi (Minneapolis: University of Minnesota Press, 1987).

Negri, Antonio, The Savage Anomaly: The Power of Spinoza's Metaphysics and Politics (Minneapolis and Oxford: University of Minnesota Press, 1991).

Nietzsche, Friedrich, Thus Spoke Zarathustra: A Book for All and None, trans. by Walter Kaufmann (Penguin Books, 1966).

Parr, Adrian, ed., The Deleuze Dictionary (Edinburgh: Edinburgh University Press, 2010).

Spinoza, Baruch, A Theologico-Political Treatise in Works of Spinoza, vol. 1, trans. by R. Elwes (New York: Dover Publications, 1951).

Ethics, trans. by Edwin Curley in A Spinoza Reader (New Jersey: Princeton University Press, 1994). 